\title{
Optimal Central Bank Design: BENCHMARKS FOR THE ECB
}

\author{
HELGE BERGER
}

\author{
CESIFO WORKING PAPER No. 1697 \\ CATEgORY 6: MONETARY POLICY AND INTERNATIONAL FinanCE \\ MARCH 2006
}

An electronic version of the paper may be downloaded

- from the SSRN website:

www.SSRN.com

- from the RePEc website:

www.RePEc.org

- from the CESifo website:

www.CESifo-group.de 


\title{
Optimal Central Bank Design: BENCHMARKS FOR THE ECB
}

\begin{abstract}
The paper discusses key elements of optimal central bank design and applies its findings to the Eurosystem. A particular focus is on the size of monetary policy committees, the degree of centralization, and the representation of relative economic size in the voting rights of regional (or sectoral) interests. Broad benchmarks for the optimal design of monetary policy committees are derived, combining relevant theoretical arguments with available empirical evidence. A new indicator compares the mismatch of relative regional economic size and voting rights in the monetary policy committees of the US Fed, the pre-1999 German Bundesbank, and the ECB over time. Based on these benchmarks, there seems to be room to improve the organization of the ECB Governing Board and current plans for reform.
\end{abstract}

JEL Code: D72, E58.

Keywords: central bank design, federal central banks, ECB, Eurosystem, ECB reform.

\author{
Helge Berger \\ Free University Berlin \\ Economics Department \\ Boltzmannstr. 8 \\ 14195 Berlin \\ Germany \\ hberger@wiwiss.fu-berlin.de
}

March 2006

I would like to thank the OeNB for its hospitality and Carsten Hefeker, Till Müller, Volker Nitsch, Nathan Sheets, and an anonymous referee for helpful comments and suggestions. 


\section{Introduction}

The institutional underpinnings of decision-making in monetary policy show a considerable amount of time-path dependency or persistence-and for most purposes this is a good thing. Well-defined rules about who gets to decide about interest rates and in what form are commonly thought of as hallmarks of central bank independence, which most observers hold to be a key ingredient for price stability. And indeed, once economic agents and markets have settled on a view of the institutional set up of a central bank, changing the rules of the game may be risky. ${ }^{1}$

Notwithstanding this persistence, remarkable changes in central bank organization do occur. Prominent examples include the early history of the U.S. Federal Reserve System (Fed) until the 1930s, the reshaping of the Bundesbank after German unification in 1992, or the granting of independence to the Swedish Riksbank and the Bank of England in the late 1990s.

Moreover, the 1990s were also a period in which a large number of central banks were founded (or restituted) in transition economies, some of which continued to adjust (or still are in the process of adjusting) their institutional framework to meet the requirements of European Union (EU) and euro area membership. A final example is the founding of the European Central Bank (ECB) itself and recent organizational changes of the ECB statute in anticipation of the enlargement of the European Economic and Monetary Union (EMU).

The reasons behind observed changes in the decision-making framework for monetary policy vary, but jointly they put a spotlight on the question exactly what we should be looking for in optimal central bank design from an economic perspective. ${ }^{2}$ While central bank design has many dimensions, three basic issues stand out: First, how many people should be responsible for monetary policy decisions? Second, how much weight should be given to central vs. regional (or sectoral) representation in decision-making? And, third, should regions (or sectors) be represented according to their economic weight? These questions are more than just of theoretical interest; they were also very much at the center of debate when EMU enlargement forced a discussion of ECB reform. ${ }^{3}$

The present paper will address these questions from an economic perspective, drawing on a still growing literature on optimal central bank design addressing these (or related) issues. As to size, Gerlach-Kristen (2002) argues that multiple-member committees handle information processing better than individuals, which suggests efficient decision-making is best handled by groups. Experimental evidence supports this view (Blinder and Morgan 2005; Lombardelli 2005). ${ }^{4}$

\footnotetext{
${ }^{1}$ In principle, this point extends to changes in monetary policy strategy-for instance, the recent discussion about the pros and cons of moving the U.S. Federal Reserve closer to an inflation targeting framework in the post-Greenspan era (see, e.g., Faust and Henderson 2004). However, in what follows the focus remains on the decision-making framework. Berger et al. (2001) provide a recent survey on central bank independence in general.

${ }^{2}$ This is not to say that actual central bank design does not also reflect political-economic forces. However, in what follows the focus will be mostly on guidelines for efficient central bank design and, thus economic arguments.

${ }^{3}$ The details of the 2003 ECB reform have been discussed extensively elsewhere-in what follows, we will focus on some relevant aspects of the reform. For a more extensive analysis of the issues involved see, among others, Hefeker (2002), Berger (2002), Dvorsky and Lindner (2003), Meade (2003), Berger et al. (2004), de Haan et al. (2004).

${ }^{4}$ Gersbach and Hahn (2001) look at related issues focusing on transparency. For an overview see Gerling et al. (2003) and Fujiki (2005). Sibert (2006) provides a comprehensive survey over a related—and highly useful— social psychology literature that looks at the effects of group size on information processing and moderation.
} 
Regarding centralization, von Hagen and Süppel (1994) and Lohmann (1998) discuss the trade-offs involved in organizing a monetary policy committee as a more or less centralized institution, arguing that, as a rule, a strong representation of regional interest in the Council leads to inefficiencies in policy making. ${ }^{5}$ Lohmann's (1997) results suggest that increasing the number of votes of regional central bank governors compared to centrally appointed Board members may result in unwanted monetary policy volatility because it increases the frequency at which the median voter position changes in the policy committee. On the other hand, the results in Moser (1999) and Hallerberg (2002) imply that one advantage of regional representation, if going along with regional powers being involved in defining the central bank's legal setup, can foster the institutions political independence by adding further veto players on the legislative side. Goodfriend (2000), Berger (2002), and Maier et al. (2003) provide yet another argument in favor of limited centralization, suggesting that economic information is mostly regional in nature, and having regional representatives within the Council could enhance the precision with which economic data is perceived and analyzed. Finally, Hefeker (2003) argues that a central bank's design will, in part, depend on the economic heterogeneity of the economic area it represents. In particular, a decision-making setup that gives much weight to regional interests can be expected in a country that exhibits considerable divergences in terms of economic structure and preferences. In this case, regional political powers are likely to resist delegation of monetary policy to a centrally appointed board that focuses its decisions on the (weighted) average of economic developments in the currency area and might have different preferences than the regions.

A third group of relevant papers is related to the question of representation. These papers take the size of the Governing Council and a (less than full) degree of centralization as given, and ask how to deal with shocks to national preferences within such a federal central bank system. Waller and Walsh (1996) suggest overlapping contracts for monetary policy committee members as an institutional device to moderate the impact of regional preference shocks-a point also stressed by Lindner (2000). Gersbach and Pachl (2004) propose flexible majority rules for committee decisions, raising majority requirements for policy proposals (motivated, for instance, by idiosyncratic national shocks) in line with the size of the desired interest rate change. The advantages of alternative decision-making arrangements, including simple majority voting, are also discussed in Bullard and Waller (2004) within a general equilibrium framework. Heisenberg (2003) favors increasing the transparency of committee decisions to reduce incentives for regionally biased policies (see also Gersbach and Hahn 2001). Finally, Berger and Müller (2005) show that over- or underrepresentation of economic size through asymmetric voting weights or rotation schemes can be helpful to moderate the impact of regional preference shocks on a monetary policy aimed at stabilizing output and inflation in a currency union overall.

In addition to exploring core arguments regarding optimal size, centralization, and representation in central bank design, the present paper adds an empirical perspective regarding the size and structure of monetary policy committees. Empirical perspective, in addition to illuminating the sometimes surprising variety in the way central banks are set up, provides orientation regarding more common (and, thus, perhaps more workable) solutions to some of the trade-offs that theory can describe but (for the most part) not decide.

The remainder of the paper is organized as follows. Section 2 will highlight the basic central bank design problem and develop broad benchmarks for monetary policy committees. Section

\footnotetext{
${ }^{5}$ Throughout the paper, the term "regional" will refer to the jurisdictional level represented in the monetary policy committee in addition to Board members. Thus, in case of the Fed, "regional" will imply the states, in case of the ECB, the countries or nations forming the union.
} 
3 will apply these benchmarks to the Eurosystem before and after euro area enlargement. Section 4 concludes.

\section{The Basic Design Problem}

The question of central bank design has many dimensions, both theoretically and empirically. In recent years, the theoretical debate has focused on a wide range of topics, from the question of transparency or communication to the virtues of inflation targeting, among other things. At the same time, European policy makers debated the pros and cons of topics such as central bank involvement in financial supervision, a Lender-of-Last-Resort function for the ECB, or its role in organizing real-time settlement systems within Europe. In what follows, however, the focus will be on the way a central bank should organize the way it reaches decisions on monetary policy.

\subsection{Size: How Many People Should Be Responsible For Monetary Policy Decisions}

Without doubt, size, that is, the number of people explicitly or implicitly involved in monetary policy decisions, is among the more important dimensions of central bank design. ${ }^{6}$ There are costs and benefits of a larger committee. As to the benefits, Gerlach-Kristen (2002) shows that multiple-member committees are better able to form a view on the state of the economy than a single individual that relies mostly on his or her own information and judgment. Faced with an uncertain environment-for instance, regarding the current or expected levels of the output gap_committee members can pool individual information, cooperate in information processing, or give more productive members a larger relative weight in the process. As a rule, this will lead to better informed decision making. ${ }^{7}$ Blinder and Morgan (2005) and Lombardelli et al. (2005) second this argument based on empirical result from experiments. A related argument is that argues that a larger monetary policy committee may keep policy from going to extremes (Blinder 1998). ${ }^{8}$ One is tempted to add that slowing down the decision-making process by means of increasing committee membership may also be a way to overcome what the theoretical literature has dubbed the stabilization bias of monetary policy (e.g., Woodford 2003)—but, clearly, there must be more efficient ways of introducing optimal inertia into interest rate setting. ${ }^{9}$

On the cost side, there is reason to believe that decision-making costs increase in committee size. While the arguments below leave little doubt that, overall, larger decision-making bodies and the resulting high decision-making costs are a disadvantage from an efficiency point of view, the issue is slightly less clear cut than it appears at first glance. For instance, Blinder and Morgan (2005) argue that, at least to a degree, small groups of individuals may be able to reach a decision at a speed broadly comparable to an individual. It seems doubtful, however,

\footnotetext{
${ }^{6}$ An important issue excluded here is the question of exactly how members are (in whatever function) selected into the MPC, raising important questions of transparency and possible political bias. Waller (1989, 1992a, 2002) discusses important elements of the broader topic of central bank appointments. A related literature, which is also not highlighted above, deals with conflicts between sectors or vested interest groups within committeessee, for instance, Herrendorf and Neumann (2003).

${ }^{7}$ Berk and Bierut (2004), too, argue that a systematic exchange of views within monetary policy committees will be beneficial because it tends to improve the quality of decision-making without necessarily resulting in dependent voting behavior. As already mentioned, Gerling et al. (2003) and Fujiki (2005) provide recent surveys of the emerging literature of decision-making in committees.

${ }^{8}$ A more recent contribution pointing in the same direction is Riboni and Ruge-Murcia (2006).

${ }^{9}$ For instance, Mirzoev (2004) argues that lowering the meeting frequency of monetary policy committees might be helpful in this regard by providing a commitment to hold policy decisions constant for a period of time.
} 
whether this extends to larger committees of the order of magnitude relevant for the ECB or Fed.

One important aspect is communication. Even if the exchange of ideas is limited to short introductory statements by each member, larger committees will easily spend considerable time just taking note of positions. In addition, actual decision-making costs are likely to have a non-linear component. For instance, if there is a need or tradition to "sound each other out" bilaterally before or during committee meetings, the time required to prepare a decision grows non-linearly in the number of members. ${ }^{10}$ Moreover, if diversity of opinion is increasing in the number of committee members, reaching an agreement might require more effort by all involved. Richard Baldwin (2001) aims in this direction, when he (somewhat exaggeratingly) suggests that -in the absence of reform - euro area enlargement will leave the ECB

Governing Council with "too many [members] to decide on where to go to dinner, let alone agree on how to run monetary policy for more than 400m people...”.

To illustrate, consider a monetary policy committee that prepares decisions through (i) a series of pre-meeting bilateral negotiations, during which each member interacts with each other member, and (ii) a "tour d'horizon", a short intervention by each member during the actual committee meeting. Assume further that both actions require a similar effort. Then the overall preparatory effort, that is, decision-making costs, $C$, of the committee would be

$$
C(n, e)=n(n+1) \frac{e}{2}
$$

with $e$ measuring effort (and/or time) and $n$ the number of committee members. ${ }^{11}$ Figure 1 depicts the exponential form of the cost function for two alternative values of $e$.

Figure 1: Decision-making costs: an illustration

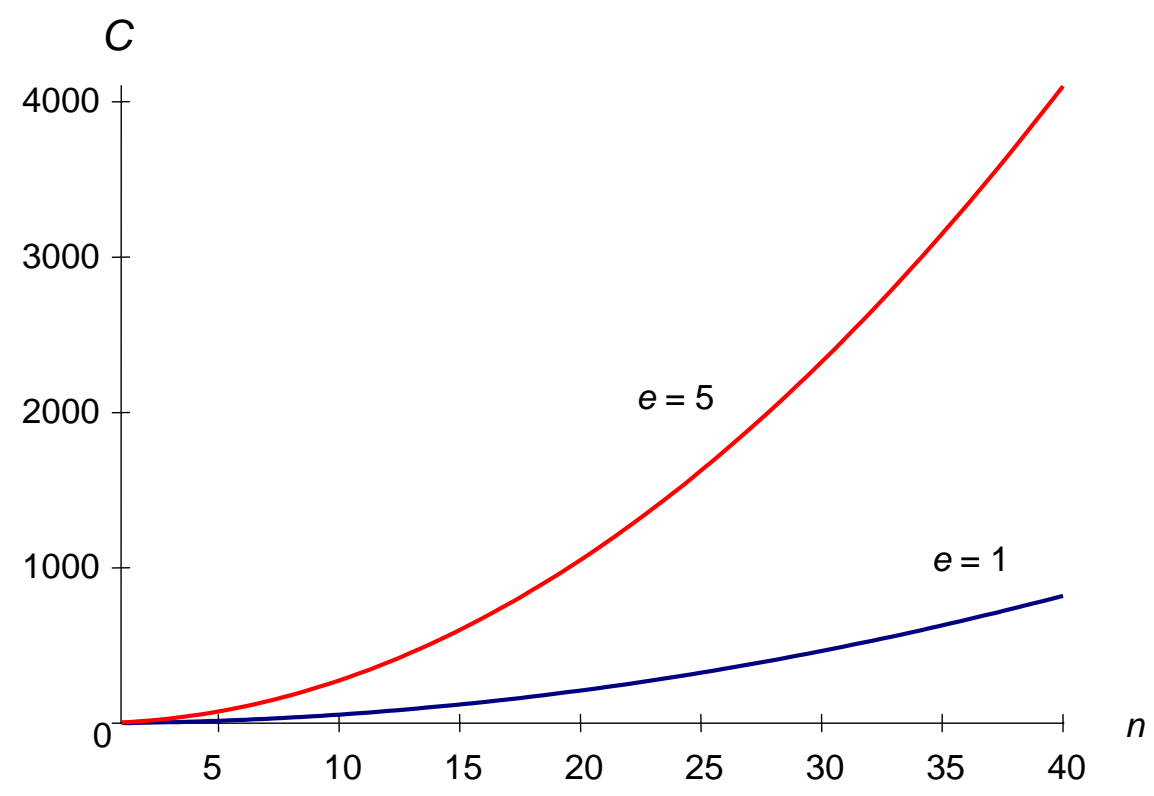

\footnotetext{
${ }^{10}$ Barber (2001) argues that bilateral meetings are a relevant practice in the ECB.

${ }^{11}$ If $n$ is the number of committee members, the number of bilateral discussions is $1 / 2 n(n-1)$.
} 
For instance, if effort was measured in minutes spend on decision-making and only five minutes were required for each "tour d'horizon" and bilateral discussion ( $e=5)$, a committee of nine would spend about four hours, a committee of 18 about 14 hours, and a committee of 27 more than 30 hours preparing a decision-no small amount of time when speed is of the essence.

For a given number of committee members, decision-making costs are also influenced by the particular way or mechanism decisions are reached. For instance, about half the close to 90 central banks surveyed by Fry et al. (2000)_including the Fed and the ECB-seem to follow a consensus-oriented approach. This approach requires all monetary policy committee members to verbally agree on a certain decision before a vote is called. Arguably, finding a consensus will take more time and effort and, thus, imply higher decision-making costs than a simple voting rule. ${ }^{12}$ This could be because under a strict voting rule some of the decisionmaking costs discussed above would not accrue (policies would simply be proposed and voted upon without prior consultation or exchange of statements) or because no additional time and effort would be spent on consensus finding and bargaining during the meeting. ${ }^{13}$

On the other hand, simple voting mechanisms — despite their possible advantages regarding decision-making costs - may have disadvantages regarding the quality of decisions. For instance, Gerlach-Kristen (2002) shows formally that optimal signal extraction procedures might deviate from simpler mechanisms, including averaging the available information or majority voting on it (i.e., using the median rather than the mean), if committee members are not equally skilled in processing information. ${ }^{14}$ In a broadly related vein, Gersbach and Pachl (2004) argue that, if preferences of decision makers have an unwanted regional bias, conventional majority rules might lead to inferior policy outcomes compared to more elaborate voting rules. They show, for example, that monetary policy would be less likely to be biased by regional considerations if majority requirements were a positive function of the size of the desired interest rate change. One implication of this type of argument is that the presence of non-voting decision-making procedures in policy committees may well be efficient in information terms. As a consequence, it would be hard to argue in favor of votingbased procedures on the basis of lower decision-making costs alone. ${ }^{15}$ Whatever the procedure, however, the question remains, how large the monetary policy committee should be.

\footnotetext{
12 These costs can be mitigated by leadership, for instance because the Board initiates and prepares many committee decisions (e.g., von Hagen and Brückner 2001), but surely that leadership ability, too, will face greater challenges as the number of committee members increases. Baldwin and others (2001) argue, for instance, that EMU enlargement might make it more difficult for the ECB Board to find sufficient support for monetary policy measures with a proper euro area perspective. See Blinder and Wyplosz (2004) for a "typology" of monetary policy committees based on the degree of internal leadership.

${ }^{13}$ The difference between consensus-based and vote-based approaches may be even larger, if there was a difference in the number of voting and non-voting members. For instance, there are 19 members that participate in the Fed's FOMC meetings - all seven Board members plus the 12 regional Fed presidents — but at any given meeting only five out of 12 regional representatives hold a right to vote. If, as already indicated, the FOMC indeed reached decisions by consensus, all members would be involved and decision-making costs are likely to be significantly higher than under a simple majority rule voting procedure that would effectively exclude nonvoting members. The same applies to the ECB’s Governing Council once more that 15 national central bank governors participate in Governing Council meetings, with only 15 voting rights rotating among them following the 2003 ECB reform (Servais 2006).

${ }^{14}$ This suggests the possibility of free-riding: if processing information is individually costly, there might be incentives to hope that other committee members provide the public good. This mechanism would add to the cost of increasing membership size (Sibert 2006). Fry et al. (2000, p.129), too, stress that informational aspects should limit the maximum size of the "ideal" monetary policy committee.

${ }^{15}$ Another problem with such a recommendation would be that it might all but impossible to force a committee not to prepare a voting decision through more or less intensive preparatory communication and negotiation.
} 
Weighing costs and benefits, the optimal size of a monetary policy committee is likely to be a moderately large number. While the information-related arguments on the benefit side suggest that single-person committees are not efficient, the overall number of participants should remain limited in the presence of exponentially increasing decision-making costs. The question remains what exactly "moderately large" means. In the absence of systematic empirical work linking the size of monetary policy committees to the achievement of policy targets, it is at least informative to note that the average size of committees is clearly larger than one and seems to be closer around ten than 20 (Lybeck and Morris 2004). The upper panel of Table 1 shows the distribution of central bank governing bodies that are concerned with setting policy goals (about 50 out of 95 countries surveyed in the sample) as well as the distribution of bodies implementing and/or deciding monetary policy. The data do not allow computing means, but the median in both categories falls into the 7-9 and 10-12 member range, respectively. The median monetary policy committee surveyed by Fry et al. (2000) has 5-10 members.

The information in the lower panel of Table 1 lists (somewhat more precise) information on the size of monetary policy committees for selected developed economies, with interesting implications for the ECB. The table suggests that the ECB's Governing Council, with currently 18 voting members is among the larger ones (even) in this sub-sample, comparable only to the Fed's FOMC or the pre-1999 Zentralbankrat of the German Bundesbank. As a rule, centralized central banks operate under smaller monetary policy committees closer to the median values found in the upper panel of Table 1. If, however, euro area membership were to increase from today's 12 to 24 members-a likely scenario, with, for instance, the eventual entrance of the ten new EU member countries as well as likely future candidates such as Rumania and Bulgaria-the Council would comprise 30 members.

Table 1. Number of Members in Governing Bodies 2003

(a) Distribution

\begin{tabular}{|l|c|c|c|c|c|l|}
\hline & \multicolumn{5}{|c|}{ Distribution of Members (in percent) } & Obs. \\
\hline & $1-3$ & $4-6$ & $7-9$ & $10-12$ & $\geq 13$ & \\
\hline $\begin{array}{l}\text { Policy } \\
\text { Committees }\end{array}$ & 4 & 28 & 47 & 11 & 10 & 50 \\
\hline $\begin{array}{l}\text { Implementation } \\
\text { Committees }\end{array}$ & 4 & 10 & 10 & 40 & 40 & 95 \\
\hline
\end{tabular}

(b) Selected Examples

\begin{tabular}{|l|c|l|c|}
\hline Bank (Federal) & Number & Bank (Central) & Number \\
\hline Bundesbank pre-1957 & 10 & Australia & 9 \\
\hline Bundesbank 1998 & 17 & Canada & 7 \\
\hline Fed & $12(19)^{\mathrm{a}}$ & New Zealand & 1 \\
\hline ECB (2001) & 18 & Sweden & 6 \\
\hline ECB (EMU24b) & $21(30)^{\mathrm{a}}$ & UK & 9 \\
\hline
\end{tabular}

Source: Lybek and Morris (2004), Berger (2002).

a: The FOMC has 12 voting members, but there are 19 regular members participating in discussion and consensus-finding. Taking into account the ECB reform of 2003, the ECB Governing Council would have 21 voting 
members and 30 members overall if euro area membership increased to a hypothetical 24 (see below).

b: "EMU24", an arbitrary example, could comprise the current 12 members plus the ten recent EU entries, as well as Bulgaria and Rumania.

The size of the ECB Governing Council will remain problematic even after the 2003 reform of the ECB statute. The reform will limit the number of voting seats of national representatives to 15 and freeze the number of voting Board members at six, restricting the maximum number of voting members to 21 in any reform scenario (ECB 2003; Servais 2006). However, if all members present at Governing Council meetings de facto continued to participate in a consensus-based decision-making process, decision-making costs would still be likely to be significantly higher than in most other central banks, including federal central bank systems. ${ }^{16}$ In this regard it is interesting to note that both the Bundesbank and the Fed reduced the size of their decision-making bodies over time (Berger 2002). As Meltzer (2004) and Eichengreen (1992) illustrate, the present statute of the Fed's FOMC is the outcome of a historical process determined, among other things, by efficiency concerns. And one of the purposes of the German Bundesbank reform of 1992 was preventing an increase in the size of the Zentralbankrat German unification would have demanded. Before 1992, each German Land had a representative in the committee, and without reform, membership would have exceeded 22-a number that, according to the Bundesbank, "would have greatly complicated that body’s decision-making processes” (Deutsche Bundesbank 1992, p.50).

\subsection{Centralization: How Much Weight for Regional (or Sectoral) Representation?}

Given the size of the monetary policy committee, another relevant design problem is the degree of centralization - that is, the relative number of seats allocated to members nominated by regional (or sectoral) and central authorities. In the case of the ECB's Governing Council or the Fed's FOMC, for instance, this means to decide the share of Board seats.

In part, the answer hinges on certain assumptions about the heterogeneity of regions and the focus of local representatives. The question of centralization would be mute, if regional representatives' preferences were identical and regions did not differ in terms of economic structure and economic development, or if they focused not on regional issues but solely on the aggregate well-being of the currency area. ${ }^{17}$ Over- or under-representation of economic weight matters, however, if there is a chance that regions differ in economic terms or that their representatives in the monetary policy committee show differences in policy priorities or signs of a 'home bias'. We will return to the issue of "home bias" and diverse references below. Regarding regional economic heterogeneity, it is probably save to assume that some of the surprisingly persistent differences in economic developments in particular within the euro area (and also, to a degree, within the US) will continue to be pose challenges to aggregate monetary policy in the foreseeable future. ${ }^{18}$

\footnotetext{
${ }^{16}$ Remarkably, this view is shared, in part, by the ECB (2003, p.83): “[Th]e participation of all [emphasis in original] governors at the meetings of the Governing Council will not necessarily make deliberations easier..." The ECB stresses, however, that “...the new voting system clearly enhances the efficiency of decision-taking.” (ibid.).

${ }^{17}$ Baldwin et al. (2001, p. 30) echo an opinion often heard among central bank watchers when they write that, in principle, "the homogeneity of American states suggests that regional representatives on the Fed are less likely to have a regional perspective than would European regional representatives”. Thus, a regional perspective in itself might be unproblematic as long the regional heterogeneity is low enough.

${ }^{18}$ See, for instance, de Haan et al (2004) for a survey of the empirical literature. Giannone and Reichlin (2005) provide a very recent discussion of the relative economic diversity of the euro area.
} 
The argument on the benefits of centralization has more than one aspect, but the general idea is that strong regional (or sectoral) representation in the monetary policy committee might lead to inefficiencies at the aggregate level. ${ }^{19} \mathrm{~A}$ first approach leading to this conclusion focuses on preferences. For instance, assuming partisan preferences over monetary policy, Lohmann (1997) argues that a centralized committee, with relative fewer members appointed at the regional level, will see fewer changes of the committee's median voter and, as a consequence, a less volatile monetary policy. Another starting point is the possible presence of a regional bias in decision making of regionally appointed committee members (von Hagen and Süppel 1994). ${ }^{20}$ To take an extreme case, assume that regional representatives focus solely on local developments while the central bank's legally defined responsibility is to ensure that an area-wide target is reached. A relevant example is the Maastricht Treaty that defines the ECB's goals as price stability based on the harmonized euro area CPI index (HCPI), computed by Eurostat as the properly weighted average of regional HCPI indices. If regionally appointed members have a regional focus and ignore the aggregate, monetary policy could deviate from that ideal. ${ }^{21}$ Thus, one benefit of increasing the relative number of centrally appointed members in a monetary policy committee could be the absence of a regional bias in decision making.

The notion of a 'home bias' of regionally appointed committee members is not completely implausible. Even though, for example, the ECB (1999, p.55) stresses that all members of the Governing Council act in "a fully independent personal capacity" and not as "national representatives,” regional economic considerations might indeed inform the behavior of governors in the Council. This assumption is certainly popular with the academic literature (see, among others, Lindner 2000, Aksoy et al. 2002, Gros and Hefeker 2002, Gersbach and Pachl 2004, and Frey 2004) as well as the media. For instance, The Economist (1998) stated with regard to the ECB that "[t]he Governing Council is supposed to set interest rates according to conditions in the euro area as a whole, but there is a risk that national governors will be unduly influenced by conditions in their home country.... A weak center, combined with strong national interests, could create conflicts that undermine the whole system's credibility.”

What is more, there is empirical evidence of regional influences in federal central bank systems. Meade and Sheets (2005; 2006) document and analyze FOMC voting patterns since the late 1960s and show that decision makers, in addition to aggregate concerns, take into account regional factors when casting votes on monetary policy. ${ }^{22}$ Meade and Sheets also find that, as a rule, regional Fed bank presidents have been more likely to dissent from the FOMC's majority vote than Board members. Berger and de Haan (2002) provide comparable evidence for the voting behavior of regional central bank governors in the Bundesbank's Zentralbankrat. They show that the probability of a regional representative to vote against the majority vote increased in the difference between their respective regional and national economic developments, in particular inflation and real GDP growth.

\footnotetext{
${ }^{19}$ For the sake of brevity, in what follows, the focus will be on regional representation alone.

${ }^{20}$ Conclusions broadly along this line were prominently featured in a number of papers written prior to the establishment of the ECB. See, among others, Lohmann (1998).

${ }^{21}$ There is an implicit assumption that the decision-making mechanism does not implicitly or explicitly weigh individual opinion in a way that leads to policies compatible with the aggregate target—we will return to this issue in Section 2.3.

${ }^{22}$ Earlier work on FOMC voting includes Havrilevsky and Gildea (1995), and Tootell (1991). Heinemann and Huefner (2004) and Meade and Sheets (2002) argue that there might even be indications of regional voting behavior in actual ECB policy. Chappell et al. (2005) provide an extensive analysis of political-economic influences on individual voting behavior in the FOMC.
} 
There are, however, also costs associated with decreasing the vote share of regional representatives in the monetary policy committee. One argument in favor of a strong regional presence rests on checks and balances. If the power to nominate committee members is shared among, say, federal and regional governments, it is less likely that monetary policy will be influenced by the political whims of either level of government, leading to a higher factual independence. ${ }^{23}$ The logic is borrowed from Moser (1999), who stresses the advantage of additional legislative veto players for the central bank's institutional independence (see also Hallerberg 2002). The Bundesbank seemed to support this view, when it called the continued presence of regional governors in the Zentralbankrat after the 1992 reform an "important element in the Bundesbank’s...independence” (Bundesbank 1992, p.49-50).

A second cost factor associated with increasing degrees of centralization may be loss of information. As pointed out by Goodfriend (2000), much of the information relevant for monetary policy originates at the regional level, and a good understanding of regional developments is of special importance in diverse economic environments such as federal currency unions. Therefore, a strong regional presence in the monetary policy committee will have its advantages also from an informational perspective (Berger 2002). Maier et al. (2003) provide an interesting formalization of the argument. ${ }^{24} \mathrm{~A}$ similar argument could be made regarding differences in transmission mechanisms of monetary policy (Gros and Hefeker 2002; Benigno 2004).

What does this imply for the optimal degree of centralization? While the discussion so far seems to favor an intermediate solution, real world monetary policy committees tend toward the extreme. Table 2 (upper panel) shows that-based on the Lybeck and Morris (2004) data - the vast majority of central bank governing bodies is fully centralized. Only eight percent of the governing bodies concerned with setting policy goals and only seven percent of the bodies in charge of policy implementation have members representing regional or sectoral interest.

\footnotetext{
${ }^{23}$ We will return to a similar argument when we discuss the issue of representation of economic size.

${ }^{24}$ Hefeker (2003) makes a related point-albeit form a political-economic perspective. He argues that regional authorities might resist a centralized design of a common central bank if their policy preferences differ from Board members and the local economy's economic structure deviates significantly from the average in the currency area.
} 
Table 2. Structure of Governing Bodies 2003

(a) Distribution

\begin{tabular}{|l|c|c|c|c|c|}
\hline & \multicolumn{4}{|c|}{ Distribution (in percent) } & Obs. \\
\hline & $\begin{array}{l}\text { Sectoral } \\
\text { Representation }\end{array}$ & \multicolumn{2}{l}{$\begin{array}{l}\text { Regional } \\
\text { Representation }\end{array}$} & \\
\hline & Yes & No & Yes & No & \\
\hline Policy Committees & 8 & 92 & 8 & 92 & 50 \\
\hline Implementation Committees & 7 & 93 & 7 & 93 & 94 \\
\hline
\end{tabular}

(b) Selected Examples

\begin{tabular}{|l|c|c|c|c|}
\hline & Board & \multicolumn{1}{|l|}{$\begin{array}{l}\text { Regional } \\
\text { Central Bank } \\
\text { Governors }\end{array}$} & $\begin{array}{l}\text { Overall } \\
\text { Council } \\
\text { Members }\end{array}$ & $\begin{array}{l}\text { Political } \\
\text { Weight of } \\
\text { Governors }\end{array}$ \\
\hline & \multicolumn{5}{|c|}{ Federal central bank models } \\
\hline Bundesbank 1998 & 8 & 9 & 17 & 52.9 \\
\hline Fed & 7 & $5(12)$ & $12(19)$ & $41.7(62.2)$ \\
\hline ECB & 6 & 12 & 18 & 66.7 \\
\hline ECB (EMU24) & 6 & $15(24)$ & $21(30)$ & $71.4(80.0)$ \\
\hline & \multicolumn{5}{|c|}{ Centralistic central bank models } \\
\hline Australia & 9 & 0 & 9 & 0 \\
\hline Canada & 7 & 0 & 7 & 0 \\
\hline New Zealand & 1 & 0 & 1 & 0 \\
\hline Sweden & 6 & 0 & 6 & 0 \\
\hline United Kingdom & 9 & 0 & 9 & 0
\end{tabular}

Source: Lybek and Morris (2004), Berger (2002).

Notes: Numbers without (with) parentheses indicate voting (non-voting) membership. See footnotes to Table 1 for details.

While most central banks laws stipulate no regional representation, those representing large federal systems or currency unions provide most of the exceptions, perhaps reflecting the greater economic and political heterogeneity compared to areas governed by more centralized central banks. Indeed, Alesina and Spolaore (2003) argue that there is a positive relation between the size (in terms of population) of a regional entity and the heterogeneity in preferences within its borders, and similar regularities might be at play regarding economic diversity. ${ }^{25}$ Looking at the examples selected for in the lower panel of Table 2, Germany, the US, and the euro area all fall into this category. ${ }^{26}$

However, even if we restrict the comparison to the US and Germany, the ECB shows the smallest degree of centralization. Focusing, first, on the distribution of voting rights, we find that the weight attached to regional representatives in the Bundesbank's Zentralbankrat and Fed's FOMC, at about 53 and 42 percent, respectively, is much lower than in the current ECB Governing Council, where regional governors hold about 67 percent of votes. This gap is bound to increase as EMU membership increases. In the hypothetical euro area with 24 members introduced earlier (see Table 1), the political weight of regional governors rises to about 71 percent despite the 2003 reform of the ECB statute. Looking instead at total

\footnotetext{
${ }^{25}$ Strictly speaking, Alesina and Spolaore (2003) are concerned with the size of nations-but the argument readily extends to trans-national bodies such as EMU. Rose (2005) provides some empirical evidence on the issue.

${ }^{26}$ Others are Switzerland and Tanzania. See Lybek \& Morris (2004).
} 
monetary policy committee membership including non-voting governors, the differences remain stark. At about 62 percent, the overall share of regional members in the FOMC is in the vicinity of today's ECB, but the ECB's figure would increase to 80 percent, if euro area membership increased to 24 .

\subsection{Representation: Should Regions be Represented According To Size?}

Taking the size of the monetary policy committee and a certain degree of centralization as given, the question is whether the voting rights of regional governors (or their otherwise defined political clout within the committee) should be in line with the economic weight of the region they represent. In other words, should the committee be organized along what could be called the "one region, one vote principle”? As with centralization, the answer depends on the heterogeneity of regions and the focus of local representatives. In what follows, we will continue to assume that regions may differ in economic as well as preference terms and that their representatives show signs of a "home bias".

Under these assumptions, an obvious cost associated with the misrepresentation of economic size is that committee decisions might deviate from the first-best, defined as the policy a decision-maker looking at the properly weighted area average would have chosen. This would be particularly worrisome if, for example, a large region underrepresented in the monetary policy committee was characterized by a systematically more volatile (or less volatile) business cycle than other regions. Or consider the case of a small region being overrepresented in the monetary policy committee with inflation below the weighted inflation average or the currency union. In this case, a majority of committee members might favor a more expansionary policy stance than a single decision-maker focused on the aggregate. To avoid regional bias in monetary policy, the optimal voting weight of a given regional representative should exactly match the represented region's economic weight. With perfect representation, committee decisions would replicate the decisions of a single decision maker focused on the aggregate. ${ }^{27}$

Another issue could be accountability and credibility. Focusing on the euro area, Servais (2006) points out that economic agents and politicians might simply not be content with a majority of small countries running monetary policy, leading to a credibility loss for the common central bank. This view is supported by Fahrholz and Mohl (2004, p.1), who argue that “considerable loss of current EMU-members' influence power especially in favour of joining Central Eastern European Countries (CEECs) results in a loss of monetary credibility of the ECB: As transparency of the decision-making process within the ECB is lacking, markets may consider the ECB to be too much inclined to the economic performances of the CEECs.”

But there might also be benefits from misrepresenting economic size. One argument in support of the "one region, one vote principle” is political stability (Berger 2002). Assume, for the sake of the argument, that regional representatives' policy preferences-e.g., their preferred inflation target or their views on the relative priorities of inflation and real policy

\footnotetext{
${ }^{27}$ This is also true if monetary policy decisions are based on a bargaining approach as long as voting rights influence fall-back positions. See Berger (2002) for a formalization of the argument. See Bindseil (2001), Baldwin et al. (2001) and Fahrenholz and Mohl (2004), among others, for a related discussion that takes into account coalition building. While the basic message stemming form this kind of analysis generally follows the gist of argument in the main text, there are differences. For instance, using the concept of a Banzhaf power index, Fahrenholz and Mohr (2004) show that, under certain conditions, the ECB reform could actually amplify problems of misrepresentation compared to the pre-reform status quo.
} 
goals - are subject to shocks of similar volatility. Then a more equal distribution of voting rights regardless of economic size can help to mitigate the aggregate impact of these shocks by allowing regional preference shocks to offset each other, thereby moderating unwanted volatility of monetary policy decisions at the union level. Of course, if preference shocks differ in variance across regions, moderating the impact at the aggregate level would require a more asymmetric distribution of voting rights, but still one that would be independent of relative economic size.

This leaves us with the question of the optimal degree of representation of economic size. Some insight can be gained from the formal discussion of the trade-offs involved. Berger and Müller (2005) model the advantages of moderating regional preference shocks at the aggregate level (through a distribution of voting weights in line with the relative stability of preferences) and the benefits from preventing regional interests distorting monetary policy in the face of national or regional economic shocks (through conditioning voting weights on relative economic size). Optimal regional representation reflects economic size and the stochastic properties of economic and preference shocks. As a rule, "one region, one vote" will not be optimal, but neither will be a perfect alignment of voting rights and relative economic size. Under plausible conditions, the formal exposition supports some overrepresentation of relative smaller countries. ${ }^{28}$

How regional governors are represented within the ECB's Governing Council and how does this compare to other federal central banks? Providing a partial answer, Figure 2 compares the relative economic size of current euro area members with the voting power allocated to the governors representing these members (upper panel). The lower panel provides the same information for the hypothetical EMU with 24 members taking into account the 2003 ECB reform. The reform, in addition to limiting the number of national central bank governors to 15, introduces an asymmetric rotation scheme organizing the way governors will exercise these voting rights once EMU membership exceeds the number of votes (ECB 2003). As euro area membership increases, governors will be divided into two and then three groups out of which they rotate into a limited number of voting seats. Country representatives will be allocated to groups by size, and groups encompassing larger countries hold more voting rights in the Governing Council. ${ }^{29}$

\footnotetext{
${ }^{28}$ Reflecting the argument made above regarding the cost of misrepresentation, an increase in economic volatility will reduce the gap between relative economic size and optimal representation of a region (lowering the weight an overrepresented region receives and increasing the weight of underrepresented ones), while an increase in the volatility of preference shocks unambiguously lowers optimal representation.

${ }^{29}$ Size is being measured by a so-called composite indicator that takes into account both relative GDP and financial market size. See, among others, Berger et al. (2004) for additional discussion of this aspect.
} 
Figure 2. Distribution of Voting rights and Economic Size in EMU

(a) Current Situation

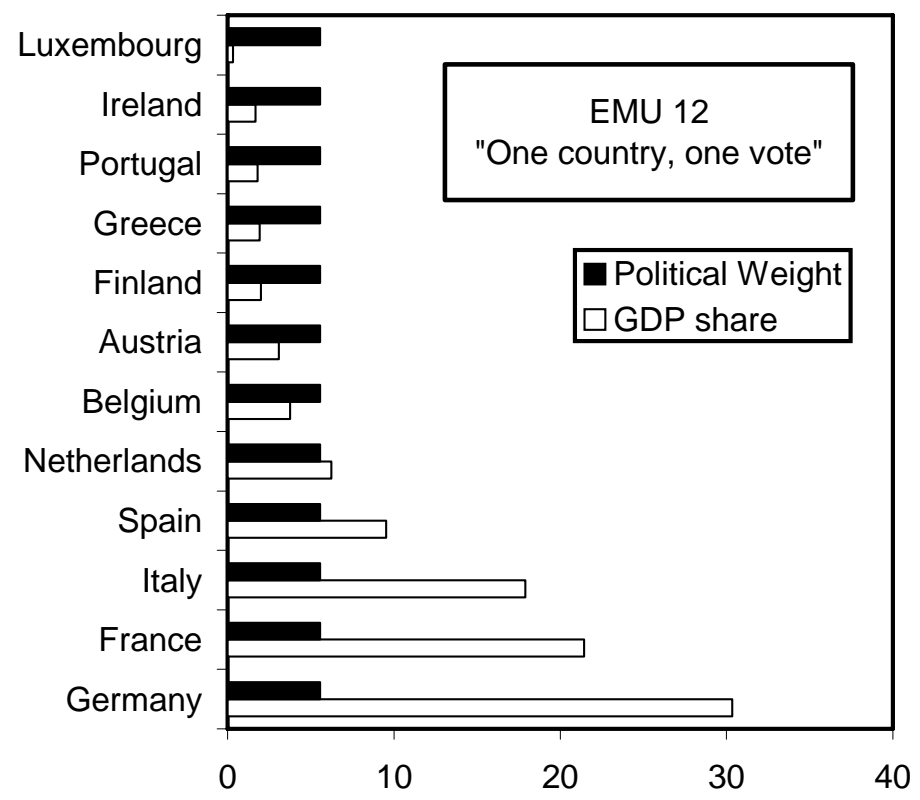

(b) Hypothetical EMU 24

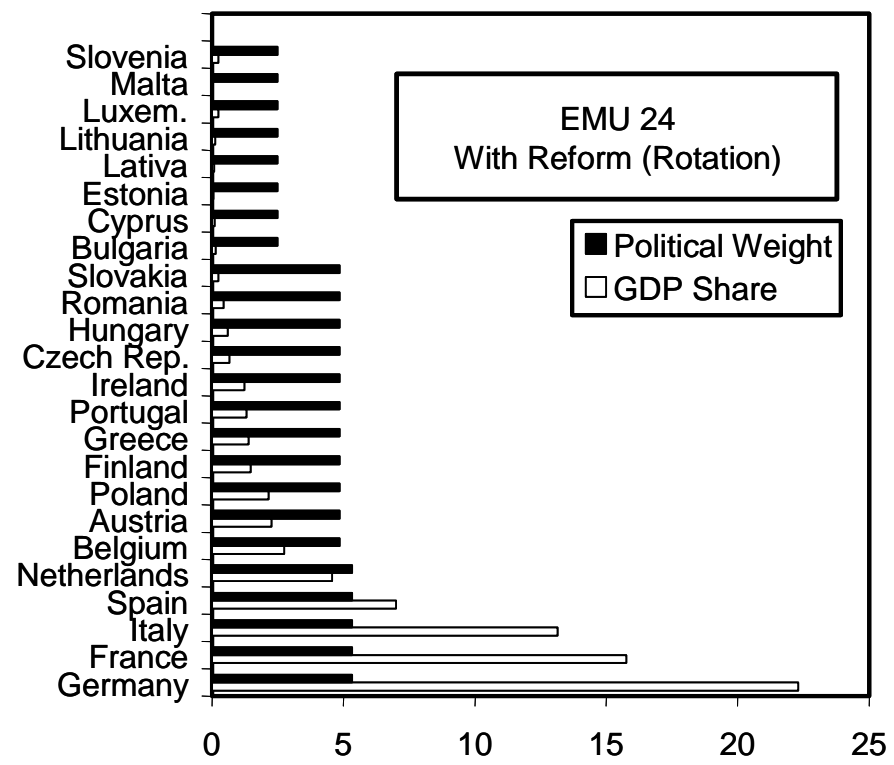

Source: ECB, IFS, and own calculations.

Note: Relative size based on GDP.

Obviously, there are stark differences between the relative economic might of regions (or countries) and the way these regional interests are represented in the ECB's Governing Council in terms of voting weights. Under the "once region, one vote" rule-formally known as the "one person, one vote" principle - seven out of 12 member countries hold voting power in excess of their economic weight. After enlargement, taking the hypothetical EMU 24 scenario as an example, this discrepancy will be even larger. Despite the rotation scheme favoring economically larger countries, as many as 20 out of 24 members may be overrepresented in term of relative economic size. It is, thus, not entirely implausible that, occasionally, an economic minority will decide monetary policy for the whole of EMU. 
The question that Figure 2 cannot answer is whether the ECB is indeed an outlier with regard to the degree of misrepresentation — after all, misrepresentation in the (pre-1999) Bundesbank or the US Federal Reserve System might be just as sizable. ${ }^{30}$ Figure 3 provides some perspective.

Figure 3. Misrepresentation of Economic Size

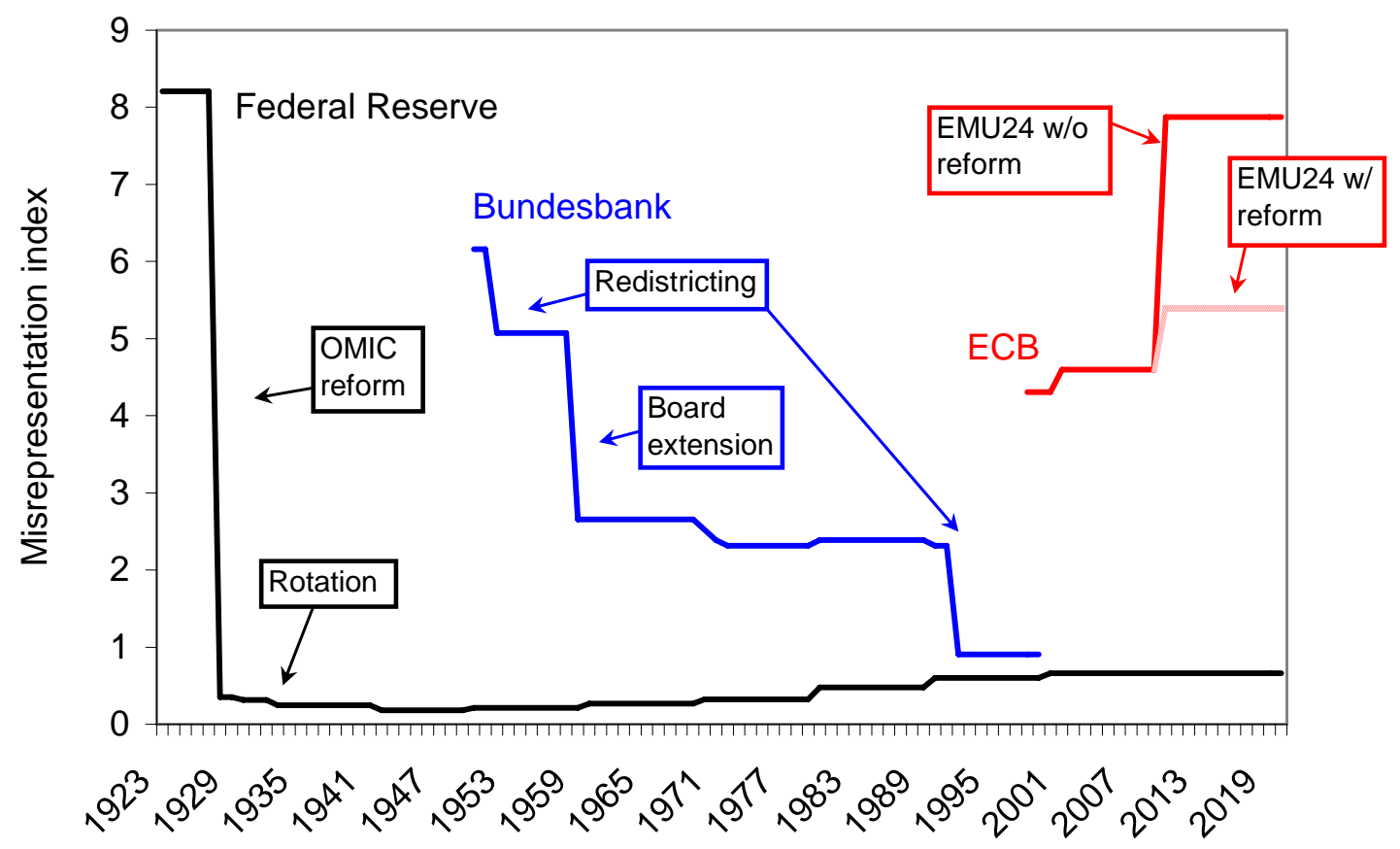

Source: US Census Bureau, US Bureau of Economic Analysis, US Federal Reserve; German Statistical office, German Bundesbank, Meltzer (2003), and own calculations.

Notes: The misrepresentation index measures the sum of the squared difference between regional vote shares in the monetary policy committee and relative economic size in a given year. Absent institutional reform, the data is updated in 10-year intervals. In case of the Federal Reserve, economic size is proxied by population shares until 1977 and GSP shares thereafter. Original population and GSP data are by state and are converted into Feddistricts on a county-by-county basis. (See main text and Appendix for a discussion of the role of the Board until the 1930s.) In the case of the Bundesbank and ECB, relative GDP shares are used. In all three cases the regional vote share is computed as the sum of the vote share of the region's representative (president or governor) in the monetary policy committee plus the region's economic weight times the Board's vote share. The assumption behind the latter is that the weight that the Board attaches to developments in each region is strictly proportional to their relative economic size. However, relative results remain qualitatively similar under alternative assumptions about Board behavior—see Table 3 below.

Figure 3 shows time series for the sum of the squared difference between regional vote shares in the monetary policy committee and relative economic size in a given year for the US, Germany, and the euro area. In case of the Federal Reserve, economic size is proxied by population shares until 1977 and GSP shares thereafter. ${ }^{31}$ The regional vote share has two components. The first component is a region's own vote share in the monetary policy committee. The second reflects the fact that the Board, if Board members take a national

\footnotetext{
${ }^{30}$ There are compelling reasons for putting the ECB's design into "historical" perspective by comparing it with the Fed. Still, Thygesen (1989, p. 91) might go too far when he states that "[i]t seems more instructive to look at the experience of an existing federal banking system which has evolved over the past 75 years than to start from more abstract notions of how such a system might be designed." Without theory, it is hard to tell whether the example set by the Fed provides worthwhile guidance.

${ }^{31}$ There is no straightforward way to pinpoint the voting share of the Board within the various predecessors of the FOMC between 1914 (when the Board held no votes) and the 1930s (when its share converged to today's level). See the Appendix for a brief synopsis of the Fed's history in this regard and the assumptions on Board voting shares based on this.
} 
perspective when casting their vote, will take regional developments into consideration. Assuming that Board members weigh regional developments according to a region's relative economic size, the second component can be calculated as the product of the Board's voting share and a region's relative economic size. While there is a range of alternative assumptions regarding the Board's voting behavior, the relative results presented in Figure 3 are quite robust. We will return to this issue below.

A number of stylized facts emerge from Figure 3. First, misrepresentation is not constant but changes over time, with institutional reform being the driving factor. While some of the developments depicted in Figure 3 are due to shifts in relative economic size, the most visible changes are clearly determined by institutional innovations. ${ }^{32}$ Second, both the Fed and the Bundesbank significantly reduced misrepresentation over time. The institutional reforms that reduced the gap between economic and political weights included, in case of the Fed, the introduction of an asymmetric rotation scheme based on relative economic size in the mid1930s, and, in case of the Bundesbank, the redrawing of the districts represented in the monetary policy committee in the 1950s and 1990s, which eliminated separate representation for some of the smaller regions. Another factor reducing misrepresentation in both cases was the strengthening of the Board-assuming that Board members are more likely to take a national rather than a regional perspective, increasing its relative vote share will help reducing the mismatch between regional representation in the monetary policy committee and economic size. ${ }^{33}$ That is part of what Eichengreen (1992, p.14) may have in mind, when he writes that " $[t]$ he early history of the Federal Reserve System...should be read as a cautionary tale. (...) It points to the advisability of reducing existing European central banks to mere branch offices of the ECB or of eliminating them entirely."34

Finally, Figure 3 clearly identifies the ECB as an extreme case: with the entry of Greece in 2001, the misrepresentation indicator for the ECB' Governing Council reached values about seven times higher than for the Fed's FOMC or the Bundesbank's Zentralbankrat. Without reform, EMU enlargement could lead to even wider gaps between economic and political weights by the 2010s. In the envisaged EMU24 scenario, the misrepresentation index is likely to stay above pre-enlargement levels despite the 2003 reform and, thus, very high relative to the two other federal central banks. ${ }^{35}$

\footnotetext{
${ }^{32}$ Some of the more important institutional changes are identified in the figure (also see the Appendix). On the history of the Fed, see, for instance, Meltzer (2003), Eichengreen (1992), and Thygesen (1989). On the Bundesbank, see, among others, Bundesbank (1992) and Berger (1997) and the references therein.

${ }^{33}$ That is the assumption underlying Figure 3-see above.

${ }^{34}$ In fact, the evolution of the Federal Reserve System was characterized by the struggle between federal (or national) and regional forces from the beginning. For instance, H. B. Joy, Director of the Chicago Fed (quoted in Meltzer (2003, p. 75) exclaimed in 1914: "I have a little feeling —in fact it is growing on me-that the Federal Reserve Board in Washington is inclined toward dominating District Banks."

${ }^{35}$ In a larger EMU with 27 members that included, in addition, the current opt-outs UK, Sweden, and Denmark, the index after reform could end up somewhat below the pre-enlargement level. See Berger (2002, Appendix).
} 
Table 3. Comparing Misrepresentation of Economic Size in the ECB in 2001

\begin{tabular}{|l|c|c|c|c|c|}
\hline & $\begin{array}{c}\text { Federal } \\
\text { Reserve }\end{array}$ & $\begin{array}{c}\text { Bundes- } \\
\text { bank }\end{array}$ & ECB & $\begin{array}{c}\text { Ratio } \\
\text { ECB/Fed }\end{array}$ & $\begin{array}{c}\text { Ratio } \\
\text { ECB/Buba }\end{array}$ \\
\hline (1) Board votes with region & 0.66 & 0.91 & 4.60 & 7.0 & 5.1 \\
\hline (2) Board does not vote with region & 5.54 & 5.70 & 33.33 & 6.0 & 5.9 \\
\hline (3) Board without voting rights & 3.79 & 3.24 & 10.34 & 2.7 & 3.2 \\
\hline
\end{tabular}

Source: US Census Bureau, US Bureau of Economic Analysis, US Federal Reserve; German Statistical office, German Bundesbank, Meltzer (2003), and own calculations.

Notes: The table shows the mispresentation index defined in Figure 3 under different assumption regarding the behavior of the Board. Board votes with region refers to figures resulting under the assumption made in Figure 3, that is, the weight that the Board attaches to developments in each region is strictly proportional to the regions' relative economic size. Board does not vote with region assumes that Board votes are neutral with regard to regions. Board without voting rights ignores the Board's votes altogether, computing the regions' voting rights as a share of regional votes only. Bundesbank data refers to 1992, ECB and Fed data to 2001. There is little change in the results if instead 2004 data is used.

Table 3 shows that similar stylized facts emerge under alternative assumptions about the behavior of Board members. In line (1), the table reproduces the misrepresentation index as computed for Figure 3 for the ECB, the Fed, and the Bundesbank. The assumption is that the Board votes "with" the regions depending on their relative economic size. Alternatively, we could assume that Board members cast their votes completely independent of regional developments (see line (2) for results) or we could simply ignore Board votes altogether in the computation of the misrepresentation index (see line (3)). As the last two columns in Table 3 reveal, the relative difference between misrepresentation in the ECB on the one hand and Fed and Bundesbank on the other is the largest under assumption (1) and broadly comparable under assumption (2). In these cases, the misrepresentation index within the ECB Governing Board reaches levels that are 5 to 7 times larger. Setting board votes to zero under assumption (3), the relative misrepresentation index for the ECB is lower, but at about 3 times the level of today's Fed and Bundesbank it still qualifies as extreme. ${ }^{36}$

If the history of the Fed and Bundesbank is any guide, the stark gap between regional representation in the ECB's Govering Board and relative economic size will (and perhaps should) not last. As Figure 3 illustrates, both federal central bank systems started at levels of misrepresentation comparable to the ECB today, but then worked systematically to reduce the gap between representation and size-not least to avoid some of the problems identified earlier. For instance, for Meltzer (2003) the relatively weak role of the Board pre-1935 within the Fed's monetary policy committee and the continuous struggle between various regional and federal interests were among the key reasons for what many have qualified as a dismal performance of US monetary policy in the 1920s and 1930s. ${ }^{37}$ And the Bundesbank (1992) stressed that the 1992 redistricting ended a period of strong (and not welcome) differences in terms of size and economic significance. ${ }^{38}$

\footnotetext{
${ }^{36}$ The type of index (e.g., quadratic rather than absolute) may influence the measured distance between institutions as well. However, the fact that the ECB comes out at the higher end compared to both Fed and Bundesbank is independent of the particular index selected.

${ }^{37}$ Based on Metzer's (2003) detailed account, this includes tensions between different regions regarding their differing representation in the FOMC and its predecessors. For an assessment of the Fed's performance see, famously, Friedman and Schwartz (1963) and Eichengreen (1992).

${ }^{38}$ The Bundesbank had inherited these differences from the Bank Deutscher Länder, its predecessor set up under Allied government in the late 1940s. In 1957, German law makers, while debating problems associated with this setup, had refrained from redistricting. See Bundesbank (1992).
} 


\section{An Application To the Eurosystem}

\subsection{Taking Stock: Where Does the ECB Stand Compared To the Benchmark?}

The discussion in Section 2 establishes certain benchmarks (however crude) that help us to broadly characterize efficient central bank design. First, the optimal size of a monetary policy committee should be a moderately large number. There is theoretical and experimental evidence implying that single-person committees are not efficient, but decision-making costs are likely to be convex in the number of committee members. This suggests that the optimally sized monetary policy committee is larger than one but not too large. Taking a cue from the (unconditional) average of central bank governing bodies, a reasonable upper bound seems to be around 10 for centralized central banks and around 20 for federal central bank systems, which the latter number backed by a significantly smaller number of examples. Taking the federal underpinnings of the Eurosystem as given, the relevant upper bound for the ECB's Governing Board would be around 20. The arguments regarding the optimal degree of centralization (i.e. ratio between Board and regional representatives) are involved, but, in general, theory suggests striking a balance between regional (or sectoral) and centralized components. For instance, one advantage of a high vote share for the centrally appointed Board is that it may help ensuring the area-wide perspective of monetary policy; disadvantages include possible limits to the central bank's factual independence from the political center and reduced access to regional information. Empirically, however, perhaps reflecting a higher degree of political and economic heterogeneity, it is mostly the federal central bank systems that are characterized by an interior solution. The majority of monetary policy committees are fully centralized. The share allocated to regional representatives in the Bundesbank and Fed systems is in the 40-50 percent range. Finally, given a share of regional representation, the optimal degree of representation of relative economic size is an issue. Balancing the trade-off, theory suggests that neither "one region, one vote" nor voting-rights fully attuned to, say, GDP shares may be optimal. More equal voting rights allow moderating policy regional preference shocks, but, at the same time, could lead to regional interests dominating aggregate monetary policy. This qualitative result is broadly in line with the fact that both Bundesbank and Fed show a non-zero degree of misrepresentation-but their example (both significantly reduced the level of misrepresentation over time) also suggest that much higher degrees may be too extreme.

At present, the ECB looks broadly in line with two out of three benchmarks. With currently 18 members, the ECB's Governing Council is about en par with the pre-1999 Zentralbankrat and the number of participating (if not voting) FOMC members. Of course, the Governing Council is much larger than the average central bank decision-making body, but so are the two other federal monetary policy committees. Looking at centralization, the ECB stands out somewhat more. At about 66 percent, the vote share commanded by regional representatives in the Governing Council clearly exceeds the ones in Bundesbank and Federal Reserve. The most striking difference between these three banks occurs regarding the representationbenchmark, however. As elaborated earlier, the degree of misrepresentation of economic size by regional voting rights is a stunning 3-7 times larger than in Fed or Bundesbank, depending on the assumptions made concerning the voting behavior of Board members (see Table 3). In other words, the "one country, one vote” principle currently enforced within the Governing Council renders the ECB an extreme case-arguably, with possible consequences for a balanced representation of the euro area.

Euro area enlargement is set to further increase the distance to the benchmark. As discussed in Section 2, in a hypothetical EMU with 24 members (including the ten recent EU entrants, as 
well as Bulgaria and Rumania) without reform, the size of the ECB Governing Council (30 members), the share of regional voting rights (80 percent), and the degree of misrepresentation (even larger than today-see Figure 3) within the Eurosystem would by far exceed the levels present in the pre-1999 Bundesbank or today’s Federal Reserve System.

The 2003 reform of the ECB statute will moderate but not reverse the impact of enlargement. First, the reform will limit the number of voting members to 15 (out of 24) national central bank representatives and six Board members — even though all 30 might participate in Governing Board meetings. Second, the reform will moderate the decline in the degree of centralization, with regional representatives holding about 70 percent of voting rights (but about 80 percent of seats) in the Governing Council. Finally, the introduction of the asymmetric rotation system will reduce the degree of misrepresentation in the EMU24 scenario to levels only moderately higher than at present. Clearly, however, while the 2003 reform works in the right direction, it will only partially compensate the effects of enlargement (at least in the scenario considered here), leaving the ECB farther away from the benchmark along all three dimension than already today. There is, in short, room for improvement.

\subsection{Principle Alternatives for Further ECB Reform}

The book on ECB reform might not be closed. Even though, as Servais (2006) reports, the 2003 ECB reform has been ratified by all member countries and is scheduled to be implemented in two stages as EMU membership increases (ECB 2003), some open issues remain and are likely to require further attention. For instance, the particularities of the asymmetric rotation scheme imply an unintended discontinuity in the difference between the voting frequencies of large and medium-sized countries in the Governing Council when EMU membership increases from 18 to $19 .{ }^{39}$ And, more generally, the introduction of new members to the euro area might lead to additional debates regarding, among other things, the way member countries are size-ranked and allocated rotation frequencies. Finally, looking back at the dynamics of central bank design in the US and Germany, there is little reason to expect that any central bank statute is cast in stone-especially when potential inefficiencies are looming.

What are options for (further) ECB reform and how do they compare against the benchmarks discussed above? Table 4 gives a brief overview over some of the possibilities. ${ }^{40}$

One option would be to substitute the planned rotation scheme by alternative setups that aim at reducing the mismatch between political and economic weights of regional governors in the Governing Council. For instance, IMF-style representation would have economically equalsized groups of countries be represented by one governor in the Governing Council. While this arrangement would reduce the de jure-size of the decision-making committee, it would not necessarily reduce decision making costs. This is because, if the mandates of group representatives were restricted, regional governors will indirectly participate in decisionmaking process at the group level. Moreover, even if the overall number of groups was roughly in line with today's setup (i.e., twelve), the resulting degree of centralization within the Governing Board would remain low.

\footnotetext{
${ }^{39}$ At this point, the difference in voting frequency drops from 23 percentage points to 1, but increases again to 7 and 11 percentage points with 20 and 21 members (see ECB 2003). One solution would be to force countries to join EMU in groups rather than individually.

${ }^{40}$ This discussion mirrors, in part, the debate on the 2003 ECB reform. For an overview see, among others Berger et al. (2004), de Haan et al. (2004) and the literature quoted therein.
} 
Table 4. Alternative ECB Reform Scenarios

\begin{tabular}{|c|c|c|c|c|}
\hline Alternative scenarios & Size & Centralization & Representation & Plausible? \\
\hline \multicolumn{5}{|l|}{ (1) Substitute rotation: } \\
\hline $\begin{array}{l}\text { (a) IMF-style representation: } \\
\text { Equal-sized groups of CBs with } \\
\text { restricted mandate }\end{array}$ & $\begin{array}{l}\text { Very large } \\
\text { (de facto) }\end{array}$ & Low & $\begin{array}{l}\text { Close(r) to } \\
\text { proportional }\end{array}$ & $\begin{array}{l}\text { Unlikely, } \\
\text { at least de jure }\end{array}$ \\
\hline $\begin{array}{l}\text { (b) Buba-style redistricting: } \\
\text { Redistricted regional CBs of } \\
\text { similar economic size }\end{array}$ & $\begin{array}{l}\text { Possibly } \\
\text { optimal }\end{array}$ & Low & $\begin{array}{l}\text { Close(r) to } \\
\text { proportional }\end{array}$ & $\begin{array}{l}\text { Unlikely, } \\
\text { at least de jure, } \\
\text { in the short-run }\end{array}$ \\
\hline $\begin{array}{l}\text { (c) EU-style weighted voting: } \\
\text { Size-weighted governor votes, all } \\
\text { participate }\end{array}$ & $\begin{array}{l}\text { Very large } \\
\text { (de facto) }\end{array}$ & Low & Proportional & Unlikely \\
\hline $\begin{array}{l}\text { (2) Move to full centralization: } \\
\text { Decision power rests with Board alone }\end{array}$ & Small & Very high & $\begin{array}{l}\text { Proportional } \\
\text { via Board }\end{array}$ & Unlikely \\
\hline $\begin{array}{l}\text { (3) Fine-tune reform: } \\
\text { More asymmetric rotation; larger } \\
\text { Board, fewer governors }\end{array}$ & $\begin{array}{l}\text { Very large } \\
\text { (de facto) }\end{array}$ & Optimal & $\begin{array}{l}\text { Close(r) to } \\
\text { proportional }\end{array}$ & Perhaps \\
\hline
\end{tabular}

Bundesbank-style redistricting of national central bank regions to create districts of more equal economic size, another principle substitute for rotation, has the potential to help reducing decision-making costs compared to the representation scheme. ${ }^{41}$ However, to avoid the problem of a simple reallocation of decision-making costs to the regional level, the "one region (or country), one vote" principle would have to be given up-that is, representatives of countries forced into one district could not be allowed to determine the behavior of the district's representative in the Governing Board. Similar to representation, the degree of centralization resulting from redistricting depends on the resulting number of districts. EUstyle weighted voting, too, has the potential to reduce misrepresentation of economic size. Weighting the votes of Governing Council members would all but guarantee that any formal decision represents the economic interest of the euro area. As with representation, however, decision making costs are likely to remain high, if actual decision-making continued to involve elements of the consensus approach. Moreover, absent a simultaneous increase in the number of voting Board members, the degree of centralization would remain low.

A second principle option, popular with many observers prior to the 2003 ECB reform, remains full centralization. Bringing the ECB to the main stream of central bank design would require giving up the existing federal structure, which would constitute an even more radical departure from the status quo than substituting the envisaged rotation scheme. The advantages of a fully centralized solution include the likely absence of a regional bias in decision-making and low decision-making costs. A possible disadvantage (not captured in Table 4, but highlighted in Section 2.2) could be a reduction in factual independence due to the absence of checks and balances.

Perhaps the greatest problem with the reform scenarios discussed so far is that their chances of being implemented are, at best, modest. This is particularly true for the centralization option, which runs against the organizational principle underlying most other European institutions and would require EMU member countries giving up even the last iota of influence on ECB policy after having given up monetary sovereignty for a seat in the

\footnotetext{
${ }^{41}$ If the number of districts was close to today's EMU membership, the overall size of the Governing Council would remain on today's level and, thus, broadly in line with the benchmark discussed in Section 2.1.
} 
Governing Council. ${ }^{42}$ Differentiating between schemes to substitute rotation, weighted voting is perhaps the least plausible option because it does achieve little more than the envisaged rotation system, and rotation is seen as more compatible (at least in formal terms) with the idea that each member casts "one vote" (ECB 2003). In comparison, redistricting and representation seem somewhat more likely to be implemented-if not formally, than perhaps on a factual basis. Redistricting could be a natural longer-run solution to the strains the ever increasing demands of full-scale membership in the Eurosystem put on smaller member countries. ${ }^{43}$ Similar forces could lead to the factual introduction of elements of representation within the envisaged rotation scheme (for instance, by smaller countries collectively organizing meeting-preparation or even voting).

The most likely further reform effort, however, is probably a fine-tuning of the rotation scheme setup-and this might not be a bad thing. This could take the form of a reduction of the regional component through a decrease in the governors' vote share in favor of the Board and a more asymmetric allocation of voting rights among regional representatives (either by changing the allocation of votes to country groups or by increasing the number of groups) to reduce misrepresentation. A further reduction in the number of Governing Council seats in an attempt to limit decision-making costs would also be conceivable, but, as with representation and weighted-voting, the impact on actual decision-making costs would depend on the Governing Council's willingness to enforce decision-making by vote and forgo consensusbased practices involving all members. Nevertheless, fine-tuning may have the potential to bring the ECB closer to the benchmark at least in two out of three areas (i.e., centralization and representation). In that sense, the most likely approach to further ECB reform might very well be among the more promising ones in efficiency terms.

\section{Concluding Remarks}

The organizational underpinnings of monetary policy-making tend to change slowly, but they do change - and often for good reasons. Like the US Fed in the 1930s and the German Bundesbank in the 1990s, the European Central Bank has recently adjusted the design of its monetary policy committee. In case of the ECB, these changes were pre-emptive, anticipating the enlargement of the European Economic and Monetary Union, the Bundesbank reacted to German unification, and the reforms of the FOMC reflected, in part, what many considered a less-than-optimal performance of the Fed during the Great Depression. In all cases, however, the ultimate goal of reform was ensuring the efficiency of decision-making.

But what exactly should we be looking for in optimal central bank design? The present paper highlights three basic topics: the question of how many people should be responsible for monetary policy decision; the issue of how much weight should be given to central and regional representation in the monetary policy committee; and the problem of identifying the degree to which regions should be represented in such a committee based to their economic weight. In addition to being at the core of a still growing literature on optimal central bank design, these topics were also at the center of debate when the ECB proposed to change its statute in 2003.

Combining theoretical arguments with empirical evidence on the actual structure of central banks, a benchmark (however rough) for optimal central bank design emerges. (i) Regarding

\footnotetext{
42 Berger et al. (2004) make a similar point.

${ }^{43}$ For instance, Lindner (2006) reports that between 1996 and 2003 the number of required trips of Austrian central bank staff to Frankfurt has more than doubled to more than 600 a year.
} 
size, there is theoretical and experimental evidence suggesting that single-person committees are not efficient, but decision-making costs are likely to be convex in committee members. Based on the (unconditional) average of central bank governing bodies, a reasonable upper bound for committee size seems to be around 20 for federal central bank systems such as the ECB. (ii) The trade-off behind the optimal degree of centralization balances, among other things, the wish to ensure an area-wide perspective with possible repercussions for central bank independence and better access to regional information. Empirically, a strong regional presence is the exception rather than the rule, and even within federal central bank systems such as the Bundesbank and Fed, regional representatives do not hold much more than 50 percent of the available votes. (iii) As to the optimal degree of representation of relative economic size, theory suggests that equal voting rights might help moderating regional preference shocks, but at the possible price of allowing regional interests to dominate monetary policy. That both the Bundesbank and Fed significantly reduced the gap between regional voting rights and relative economic size over time suggests that much higher degrees may be too extreme.

While there are some obvious caveats to this kind of reasoning, applying the resulting benchmarks to the ECB can be instructive. ${ }^{44}$ The paper finds the current design of the ECB to be broadly in line with recommendations, with the possible exception of a relative high mismatch between relative economic size and regional voting rights in the Governing Council. However, the picture changes once EMU enlargement is taken into account. Even when factoring in the effects of the 2003 ECB reform - the reform establishes an upper limit for committee size and introduces an asymmetric rotation (and this voting) scheme that favors larger regions in case of enlargement - the ECB might be significantly "off” the benchmark once EMU membership increases. For instance, in a scenario with 24 euro area members (including the new EU entrants as well as Bulgaria and Rumania), up to 30 decision-makers might participate in Governing Board meetings, the voting share of regional representatives would reach about 70 percent, and the degree of misrepresentation of relative economic size will be at least three times the level at the Fed or the pre-1999 Bundesbank.

Against this background, a refinement of the planed asymmetric rotation scheme would have advantages. Such fine-tuning could reduce the relative vote share of regional (i.e., national) governors in favor of the Board and, in addition, adjust regional voting rights to better reflect relative economic size and reduce misrepresentation. In addition, a further reduction in the number of Governing Council seats could help to limit decision-making costs, even though the effect of such a measure would, in part, depend on the ECB's willingness to forgo consensus-based practices involving all members present. An added advantage of fine-tuning the current design of the ECB's monetary policy committee along these lines would be that it follows the pattern of the 2003 reform. Thich might enhance its feasibility in political terms compared to more radical proposals such as UK-style full centralization of euro area monetary policy.

\footnotetext{
${ }^{44}$ First, these benchmarks are based on theoretical arguments that are, more often than not, qualitative and, therefore, hard to translate into hands-on guidelines for institutional design. In addition, where empirical results have been used, these stylized facts are descriptive rather than based on an explicit analysis of determinants of central-banking success.
} 


\section{References}

Aksoy, Yunus, Paul de Grauwe, and Hans Dewachter (2002), Do Asymmetries Matter for European Monetary Policy? European Economic Review, 46(3), 443-69.

Alesina, Alberto and Enrico Spolaore (2003), The Size of Nations, The MIT Press: Cambridge, MA.

Baldwin, Richard (2001), The ECB’s Number Problems, Financial Times (London), December 4.

Baldwin, Richard, Erik Berglöf, Francesco Giavazzi, and Mika Widgren (2001), Preparing the ECB for Enlargement, CEPR Policy Paper, 6, CEPR: London.

Bank of England

Barber, T., (2001), Casting Light on the ECB, Financial Times Online (London), September 6.

Benigno, Pierpaolo (2004), Optimal Monetary Policy in a Currency Area, Journal of International Economics, 63(2), 293-320.

Berger, Helge (1997), The Bundesbank’s Path to Independence. Evidence from the 1950's, Public Choice, 93, 427-53.

Berger, Helge (2002), The ECB and Euro-Area Enlargement, IMF Working Paper, 02/175.

Berger, Helge and Jakob de Haan (2002), Are Small Countries too Powerful Within the ECB? Atlantic Economic Journal, 30 (3), 1-20.

Berger, Helge and Till Müller (2004). How Should Large and Small Countries Be Represented in a Currency Union? CESifo Working Paper, 1344.

Berger, Helge, Jakob de Haan, and Robert Inklaar (2004), Restructuring the ECB, in: Helge Berger and Thomas Moutos (eds.), Managing EU Enlargement, Cambridge: The MIT Press, 29-66.

Berger, Helge, Sylvester Eijffinger and Jakob de Haan (2001), Central Bank Independence: An Update of Theory and Evidence, Journal of Economic Surveys, 2001, 15(1), pp. 3-40.

Berk, Jan Marc and Beata K. Bierut (2004), The Effects of Learning in Interactive Monetary Policy Committees, Netherlands Central Bank, MEB Series, 2004-01.

Bindseil, Ulrich (2001), A Coalition-Form Analysis of the "One Country-One Vote” Rule in the Governing Council of the European Central Bank, International Economic Journal, 15(1), 141-64.

Blinder, Alan (1998), Central Banking in Theory and Practice. The MIT Press: Cambridge, MA.

Blinder, Alan and Charles Wyplosz (2004), Central Bank Talk: Committee Structure and Communication Policy, Mimeo, Princeton and Graduate Institute of International Studies.

Blinder, Alan and John Morgan (2005), Are Two Heads Better Than One? Monetary Policy by Committee, Journal of Money, Credit and Banking, 37(5), 798-811.

Bullard, James and Christopher Waller (2004), Central Bank Design in General Equilibrium, Journal of Money, Credit, and Banking, 36(1), 95-113.

Bundesbank (1992), Restructuring the Bundesbank, Monthly Report, August, 48-53.

Chappell, Henry, Rob Roy McGregor, and Todd Vermilyea (2005), Committee Decisions on Monetary Policy, Evidence from Historical Records of the Federal Open Market Committee, The MIT Press: Cambridge, MA.

Dvorsky, Sandra and Isabella Lindner (2003), Institutionelle Entwicklungen im ESZB. Anpassung der Stimmrechtsmodalitäten im EZB-Rat, Österreichische Nationalbank, Berichte und Studien, 2, 144-59.

Eichengreen, Barry (1992), Designing a Central bank for Europe: A Cautionary Tale from the Early Years of the Federal Reserve System”, in: Matthew Canzoneri, Vittorio Grilli, and Paul Masson (eds.), Establishing a Central Bank: Issues in Europe and Lessons from the US, Cambridge University Press, Cambridge, 13-40. 
European Central Bank (ECB) (1999), The Institutional Framework of the European System of Central Banks, Monthly Bulletin, July, 55-63.

European Central Bank (ECB) (2003), The Adjustment of Voting Modalities in the Governing Council, Monthly Bulletin, May, 73-83.

European Union (1997), Consolidated Version of the Treaty Establishing the European Community, Official Journal of the European Communities, C 340, November 10.

Fahrholz, Christian and Philipp Mohl (2004), EMU-enlargement and the Reshaping of Decision-making within the ECB Governing Council: A Voting-Power Analysis, Ezoneplus Working Paper, 23.

Faust, Jon and Dale Henderson (2004), Is Inflation Targeting Best-Practice Monetary Policy? Federal Reserve Bank of St. Louis Review, 86(4), 117-43.

Fitoussi, Jean-Paul and Jerome Creel (2002), How To Reform the European Central Bank, CER: London.

Frey, Rainer (2004), Welfare Implications of the Design of a Currency Union in Case of Member Countries of Different Sizes and Output Persistence, Deutsche Bundesbank Discussion Paper, Series 1, 15/2004 (forthcoming in: Kredit und Kapital).

Friedman, Milton and Anna Schwartz (1963), A Monetary History of the United States 19671960, Princeton University Press: Princeton.

Fry, Maxwell, Deanne Julius, Lavan Mahadewa, Sandra Roger, and Gabriel Sterne (2000), Key Issues in the Choice of Monetary Policy Framework, in: Lavan Mahadeva and Gabriel Sterne (eds), Monetary Frameworks in a Global Context, Routledge: London, 1216.

Fujiki, Hiroshi (2005), The Monetary Policy Committee and the Incentive Problem: A Selective Survey, Monetary and Economic Studies, October), 37-82.

Gerlach-Kristen, Petra (2002), Monetary Policy Committees and Interest-Rate Setting, European Economic Review, forthcoming.

Gerling, Kerstin, Hans Peter Grüner, Alexandra Kiel, and Elisabeth Schulte (2003), Information Acquisition and Decision Making in Committees: A Survey, ECB Working Paper, 256.

Gersbach, Hans and Bernhard Pachl (2004), Flexible Rules for Central Banks, Mimeo, University of Heidelberg.

Gersbach, Hans and Volker Hahn (2001), Voting Transparency and Conflicting Interests in Central-Bank Councils, Mimeo, University of Heidelberg.

Giannone, Domenico and Lucrezia Reichlin (2005), Trends and Cycles in the Euro Area: How Much Heterogeneity and Should We Worry About It? Mimeo, Universite' Libre de Bruxelles.

Goodfriend, Marvin (2000), The Role of a Regional Bank in a System of Central Banks, Federal Reserve Bank of Richmond Economic Quarterly, Winter, 7-25.

Gros, Daniel [Chairman] and others (2002), The Euro at 25, Special Report of the CEPS Macroeconomic Policy Group, CEPS: Brussels.

Gros, Daniel and Carsten Hefeker (2002), One Size Must Fit All: National Divergences in a Monetary Union, German Economic Review, 3 (3), 247-62.

Haan, Jakob de, Helge Berger, and Robert Inklaar (2004), Is the ECB Too Decentralized?, in: Hans-Werner Sinn, Mika Widgren, and Marko Köthenburger (eds.), European Monetary Integration, Cambridge: The MIT Press, 71-97.

Hagen, Jürgen von and Matthias Brückner (2001), Monetary Policy in Unknown Territory,

The European Central Bank in the Early Years, ZEI Discussion Paper, B18.

Hagen, Jürgen von and Ralph Süppel (1994), Central Bank Constitutions for Federal Monetary Unions, European Economic Review, 38, 774-82.

Hallerberg, Mark (2002) Veto Players and Monetary Commitment Technologies. International Organization, 56 (4), 775-802. 
Havrilevsky,T. and Gildea J. (1995), The Bias of Federal Reserve Presidents, Economic Inquiry, 33, 274-284.

Hefeker, Carsten (2002), Monetary Policy in a Union of 27: Enlargement and Reform Options, Intereconomics, November/December, 315-20.

Hefeker, Carsten (2003), Federal Monetary Policy, Scandinavian Journal of Economics, 105, 641-59.

Heinemann, Friedrich and Felix Huefner (2004), Is the View from the Eurotower Purely European? National Divergence and ECB Interest Rate Policy, Scottish Journal of Political Economy, 51(4), 544-58.

Heisenberg, Dorthee (2003), Cutting the bank Down to Size: Efficient and Legitimate Decision-Making in the European Central Bank After Enlargement, Journal of Common Market Studies, 41(3), 397-420.

Herrendorf, Berthold and Manfred Neumann (2003), The Political Economy of Inflation, Labour Market Distortions and Central Bank Independence, Economic Journal, 113, 4364.

Linder, Isabella (2006), The Austrian Experience with Institutional Changes in the European Integration Process, Typescript.

Lindner, Axel (2000), Long-Term Appointment of Central Bankers: Cost and Benefits, European Journal of Political Economy, 16, 639-54.

Lohmann, Susanne (1997), Partisan Control of the Money Supply and Decentralized Appointment Powers, European Journal of Political Economy, 13, 225-46.

Lohmann, Susanne (1998), Federalism and Central Bank Independence: The Politics of German Monetary Policy, World Politics, 50, 401-46.

Lombardelli, Clare, James Proudman, and James Talbot (2005), Committees Versus Individuals: An Experimental Analysis of Monetary Policy Decision Making, International Journal of Central Banking, 1(1), 181-205.

Lybeck, Tonny and JoAnne Morris (2004), Central bank Governance: A Survey of Boards and Arrangements, IMF Working Paper, 04/226.

Maier, Philipp, Beata Bierut, and Robert-Paul Berben (2003), The Role of Regional Information in the Optimal Composition of a Committee, MEB Discussion Paper (De Nederlandsche Bank), 2003-08.

Meade Ellen and Nathan Sheets (2005), Regional Influences on FOMC Voting Patterns, Journal of Money, Credit and Banking, 37(4), 661-677.

Meade Ellen and Nathan Sheets (2006), Documenting FOMC Voting Patterns, Typescript.

Meade, Ellen (2003), A (Critical) Appraisal of the ECB's Voting Reform, Intereconomics, forthcoming.

Meltzer, Allan (2003), A History of the Federal Reserve, Volume I: 1913-1951, The University of Chicago Press: Chicago, Il.

Mirzoev, Tokhir (2004), Limited Commitment, Inaction and Optimal Monetary Policy, Typescript, Ohio State University.

Moser, Peter (1999), Checks and Balances, and the Supply of Central Bank Independence, European Economic Review, 43, 1569-93.

Riboni, Alessandro and Francisco Ruge-Murcia (2006), The Dynamic (In)efficiency of Monetary Policy by Committee, Typescript, University of Montreal.

Rose, Andrew (2005), Size Really Doesn't Matter: In Search of a National Scale Effect, Mimeo, University of California, Berkeley.

Servais, Dominique (2006), The Future Voting Modalities of the ECB Governing Council, Typescript.

Sibert, Anne (2006), Central Banking by Committee, DNB Working Paper, 91.

The Economist (1998), Euro Towers or Fawlty Towers?, 31 October, 1998. 
Thygesen, Niels (1989), Decentralization and Accountability within the Central Bank: Any Lessons from the US Experience for the Potential organization of a European Central Banking Institution? in: Paul de Grauwe and Theo Peeters (eds.), The ECU and European Monetary Integration, MacMillan: London, 91- 114.

Tootell, G. (1991), Regional conditions and the FOMC votes of District Presidents, New England Economic Review, March-April, 3-16.

Waller, Christopher (1989), Macroeconomic Policy Games and Central Bank Politics, Journal of Money, Credit and Banking, 21 (November), 422-31.

Waller, Christopher (1992), A Bargaining Model of Partisan Appointments to the Central Bank, Journal of Monetary Economics, 29 (June), 411-28.

Waller, Christopher (2002), Policy Boards and Policy Smoothing, Quarterly Journal of Economics, 115 (February), 305-39.

Waller, Christopher and Carl Walsh (1996), Central Bank Independence, Economic Behavior, and Optimal Term Length, American Economic Review, 85(5), 1139-54.

Woodford, Michael (2003), Interest \& Prices: Foundations of a Theory of Monetary Policy. Princeton University Press: Princeton. 


\section{Appendix: A (Brief) Synopsis of the Role of the Board in the Fed's Monetary Policy Committee}

\begin{tabular}{|c|c|c|c|c|c|c|}
\hline Name & Year & Banks & Board & Sum & $\begin{array}{l}\text { Share } \\
\text { Banks }\end{array}$ & Comments \\
\hline $\begin{array}{l}\text { Governors } \\
\text { Conference }\end{array}$ & 1914 & 12 & $5+2$ & 19 & 100 & $\begin{array}{l}\text { Board with } 5 \text { members from districts (not } 2 \text { out of } 1 \text { ), } 2 \text { government members (Secretary of the Treasury, } \\
\text { Comptroller of the Currency). Law stipulates that authority for open market policy rests solely with } \\
\text { regional Federal Reserve Banks, which are more interested in earnings than national monetary policy } \\
\text { concerns. As a consequence, the possibility to opt out of coordinated open market policies remains } \\
\text { intact (while gradually reduced) until Banking Act of 1935: "local option”. }\end{array}$ \\
\hline $\begin{array}{l}\text { Committee on } \\
\text { Centralized Purchases } \\
\text { and Sales }\end{array}$ & 1922 & 5 & $5+2$ & 12 & 100 & $\begin{array}{l}\text { CCPS coordinates Reserve Bank open market actions, makes suggestions. Fed NY emerges as dominant } \\
\text { force, while taking into account the interest of other Federal Reserve Banks-not least to keep the Board } \\
\text { at bay. Participation of Reserve Banks in the suggested open market actions remains voluntary, though. }\end{array}$ \\
\hline $\begin{array}{l}\text { Open Market } \\
\text { Investment } \\
\text { Committee (1) }\end{array}$ & 1923 & 5 & $6+2$ & 13 & $\sim 90$ & $\begin{array}{l}\text { Agricultural interests gain a seat in the Board. Board forces abolition of CCPS, renaming it OMIC, and } \\
\text { trying to put it under Board authority. While the GC rejected this, the Board gained some supervisory } \\
\text { power over open market operations. Before that point, such power only existed with regard to discount } \\
\text { rate decisions. Still, participation of Reserve Banks in the coordination of open market policy remained } \\
\text { voluntary. }\end{array}$ \\
\hline $\begin{array}{l}\text { Open Market } \\
\text { Investment } \\
\text { Committee (2) }\end{array}$ & 1928 & 12 & $6+2$ & 20 & $\sim 85$ & $\begin{array}{l}\text { Board succeeded in reducing the power of the FedNY by making the original OMIC responsible to all } \\
\text { Federal Reserve Banks; the original OMIC continued as an executive committee }\end{array}$ \\
\hline $\begin{array}{l}\text { Open Market Policy } \\
\text { Conference }\end{array}$ & 1930 & 12 & $6+2$ & 20 & $\sim 80$ & $\begin{array}{l}\text { Name change mainly the result of a bungled attempt by the Board to gain veto power over open market } \\
\text { policy decisions by the Federal reserve banks (similar to discount policy). Little else changed. For } \\
\text { instance, the Federal Reserve Banks on Chicago and Boston often abstain from coordinated open market } \\
\text { operations. (Benjamin Strong, dominant Governor of the NYFed, died earlier.) }\end{array}$ \\
\hline $\begin{array}{l}\text { Federal Open Market } \\
\text { Committee (1) }\end{array}$ & 1933 & 12 & $6+2$ & 20 & $\sim 70$ & $\begin{array}{l}\text { Similar to OMPC in all but its name (Banking Act of 1933). Board gains some powers of Federal } \\
\text { Reserve Banks, including wider supervisory powers on open market operations. However, Federal } \\
\text { Reserves still had a "local option". Chicago, for example, made use of this in } 1933 \text { (the suggested } \\
\text { purchases threatened profits) }\end{array}$ \\
\hline $\begin{array}{l}\text { Federal Open Market } \\
\text { Committee (2) }\end{array}$ & 1935 & 5 & 7 & 12 & 42 & $\begin{array}{l}\text { Asymmetric representation scheme for the } 5 \text { Reserve Bank seats ( } 1 \text { representative selected each year, no } \\
\text { rotation). Board no without ex officio government members, but reduced by } 1 \text { to } 7\end{array}$ \\
\hline $\begin{array}{l}\text { Federal Open Market } \\
\text { Committee (3) }\end{array}$ & 1942 & 5 & 7 & 12 & 42 & Asymmetric rotation scheme for the 5 Reserve Banks. Groups changed from 1935 \\
\hline
\end{tabular}

Source: Meltzer (2003), Eichengreen (1992). 


\section{CESifo Working Paper Series}

(for full list see www.cesifo-group.de)

1633 Michiel Evers, Ruud A. de Mooij and Daniel J. van Vuuren, What Explains the Variation in Estimates of Labour Supply Elasticities?, December 2005

1634 Matthias Wrede, Health Values, Preference Inconsistency, and Insurance Demand, December 2005

1635 Hans Jarle Kind, Marko Koethenbuerger and Guttorm Schjelderup, Do Consumers Buy Less of a Taxed Good?, December 2005

1636 Michael McBride and Stergios Skaperdas, Explaining Conflict in Low-Income Countries: Incomplete Contracting in the Shadow of the Future, December 2005

1637 Alfons J. Weichenrieder and Oliver Busch, Artificial Time Inconsistency as a Remedy for the Race to the Bottom, December 2005

1638 Aleksander Berentsen and Christopher Waller, Optimal Stabilization Policy with Flexible Prices, December 2005

1639 Panu Poutvaara and Mikael Priks, Violent Groups and Police Tactics: Should Tear Gas Make Crime Preventers Cry?, December 2005

1640 Yin-Wong Cheung and Kon S. Lai, A Reappraisal of the Border Effect on Relative Price Volatility, January 2006

1641 Stefan Bach, Giacomo Corneo and Viktor Steiner, Top Incomes and Top Taxes in Germany, January 2006

1642 Johann K. Brunner and Susanne Pech, Optimum Taxation of Life Annuities, January 2006

1643 Naércio Aquino Menezes Filho, Marc-Andreas Muendler and Garey Ramey, The Structure of Worker Compensation in Brazil, with a Comparison to France and the United States, January 2006

1644 Konstantinos Angelopoulos, Apostolis Philippopoulos and Vanghelis Vassilatos, RentSeeking Competition from State Coffers: A Calibrated DSGE Model of the Euro Area, January 2006

1645 Burkhard Heer and Bernd Suessmuth, The Savings-Inflation Puzzle, January 2006

1646 J. Stephen Ferris, Soo-Bin Park and Stanley L. Winer, Political Competition and Convergence to Fundamentals: With Application to the Political Business Cycle and the Size of Government, January 2006 
$1647 \mathrm{Yu}-\mathrm{Fu}$ Chen, Michael Funke and Kadri Männasoo, Extracting Leading Indicators of Bank Fragility from Market Prices - Estonia Focus, January 2006

1648 Panu Poutvaara, On Human Capital Formation with Exit Options: Comment and New Results, January 2006

1649 Anders Forslund, Nils Gottfries and Andreas Westermark, Real and Nominal Wage Adjustment in Open Economies, January 2006

1650 M. Hashem Pesaran, Davide Pettenuzzo and Allan G. Timmermann, Learning, Structural Instability and Present Value Calculations, January 2006

1651 Markku Lanne and Helmut Luetkepohl, Structural Vector Autoregressions with Nonnormal Residuals, January 2006

1652 Helge Berger, Jakob de Haan and Jan-Egbert Sturm, Does Money Matter in the ECB Strategy? New Evidence Based on ECB Communication, January 2006

1653 Axel Dreher and Friedrich Schneider, Corruption and the Shadow Economy: An Empirical Analysis, January 2006

1654 Stefan Brandauer and Florian Englmaier, A Model of Strategic Delegation in Contests between Groups, January 2006

1655 Jan Zápal and Ondřej Schneider, What are their Words Worth? Political Plans and Economic Pains of Fiscal Consolidations in New EU Member States, January 2006

1656 Thiess Buettner, Sebastian Hauptmeier and Robert Schwager, Efficient Revenue Sharing and Upper Level Governments: Theory and Application to Germany, January 2006

1657 Daniel Haile, Abdolkarim Sadrieh and Harrie A. A. Verbon, Cross-Racial Envy and Underinvestment in South Africa, February 2006

1658 Frode Meland and Odd Rune Straume, Outsourcing in Contests, February 2006

1659 M. Hashem Pesaran and Ron Smith, Macroeconometric Modelling with a Global Perspective, February 2006

1660 Alexander F. Wagner and Friedrich Schneider, Satisfaction with Democracy and the Environment in Western Europe - a Panel Analysis, February 2006

1661 Ben J. Heijdra and Jenny E. Ligthart, Fiscal Policy, Monopolistic Competition, and Finite Lives, February 2006

1662 Ludger Woessmann, Public-Private Partnership and Schooling Outcomes across Countries, February 2006

1663 Topi Miettinen and Panu Poutvaara, Political Parties and Network Formation, February 2006 
1664 Alessandro Cigno and Annalisa Luporini, Optimal Policy Towards Families with Different Amounts of Social Capital, in the Presence of Asymmetric Information and Stochastic Fertility, February 2006

1665 Samuel Muehlemann and Stefan C. Wolter, Regional Effects on Employer Provided Training: Evidence from Apprenticeship Training in Switzerland, February 2006

1666 Laszlo Goerke, Bureaucratic Corruption and Profit Tax Evasion, February 2006

1667 Ivo J. M. Arnold and Jan J. G. Lemmen, Inflation Expectations and Inflation Uncertainty in the Eurozone: Evidence from Survey Data, February 2006

1668 Hans Gersbach and Hans Haller, Voice and Bargaining Power, February 2006

1669 Françoise Forges and Frédéric Koessler, Long Persuasion Games, February 2006

1670 Florian Englmaier and Markus Reisinger, Information, Coordination, and the Industrialization of Countries, February 2006

1671 Hendrik Hakenes and Andreas Irmen, Something out of Nothing? Neoclassical Growth and the 'Trivial' Steady State, February 2006

1672 Torsten Persson and Guido Tabellini, Democracy and Development: The Devil in the Details, February 2006

1673 Michael Rauber and Heinrich W. Ursprung, Evaluation of Researchers: A Life Cycle Analysis of German Academic Economists, February 2006

1674 Ernesto Reuben and Frans van Winden, Reciprocity and Emotions when Reciprocators Know each other, February 2006

1675 Assar Lindbeck and Mats Persson, A Model of Income Insurance and Social Norms, February 2006

1676 Horst Raff, Michael Ryan and Frank Staehler, Asset Ownership and Foreign-Market Entry, February 2006

1677 Miguel Portela, Rob Alessie and Coen Teulings, Measurement Error in Education and Growth Regressions, February 2006

1678 Andreas Haufler, Alexander Klemm and Guttorm Schjelderup, Globalisation and the Mix of Wage and Profit Taxes, February 2006

1679 Kurt R. Brekke and Lars Sørgard, Public versus Private Health Care in a National Health Service, March 2006

1680 Dominik Grafenhofer, Christian Jaag, Christian Keuschnigg and Mirela Keuschnigg, Probabilistic Aging, March 2006 
1681 Wladimir Raymond, Pierre Mohnen, Franz Palm and Sybrand Schim van der Loeff, Persistence of Innovation in Dutch Manufacturing: Is it Spurious?, March 2006

1682 Andrea Colciago, V. Anton Muscatelli, Tiziano Ropele and Patrizio Tirelli, The Role of Fiscal Policy in a Monetary Union: Are National Automatic Stabilizers Effective?, March 2006

1683 Mario Jametti and Thomas von Ungern-Sternberg, Risk Selection in Natural Disaster Insurance - the Case of France, March 2006

1684 Ken Sennewald and Klaus Waelde, "Itô's Lemma" and the Bellman Equation for Poisson Processes: An Applied View, March 2006

1685 Ernesto Reuben and Frans van Winden, Negative Reciprocity and the Interaction of Emotions and Fairness Norms, March 2006

1686 Françoise Forges, The Ex Ante Incentive Compatible Core in Exchange Economies with and without Indivisibilities, March 2006

1687 Assar Lindbeck, Mårten Palme and Mats Persson, Job Security and Work Absence: Evidence from a Natural Experiment, March 2006

1688 Sebastian Buhai and Coen Teulings, Tenure Profiles and Efficient Separation in a Stochastic Productivity Model, March 2006

1689 Gebhard Kirchgaessner and Silika Prohl, Sustainability of Swiss Fiscal Policy, March 2006

1690 A. Lans Bovenberg and Peter Birch Sørensen, Optimal Taxation and Social Insurance in a Lifetime Perspective, March 2006

1691 Moritz Schularick and Thomas M. Steger, Does Financial Integration Spur Economic Growth? New Evidence from the First Era of Financial Globalization, March 2006

1692 Burkhard Heer and Alfred Maussner, Business Cycle Dynamics of a New Keynesian Overlapping Generations Model with Progressive Income Taxation, March 2006

1693 Jarko Fidrmuc and Iikka Korhonen, Meta-Analysis of the Business Cycle Correlation between the Euro Area and the CEECs, March 2006

1694 Steffen Henzel and Timo Wollmershaeuser, The New Keynesian Phillips Curve and the Role of Expectations: Evidence from the Ifo World Economic Survey, March 2006

1695 Yin-Wong Cheung, An Empirical Model of Daily Highs and Lows, March 2006

1696 Scott Alan Carson, African-American and White Living Standards in the $19^{\text {th }}$ Century American South: A Biological Comparison, March 2006

1697 Helge Berger, Optimal Central Bank Design: Benchmarks for the ECB, March 2006 